INSIGHTS INTO REGIONAL DEVELOPMENT

ISSN 2669-0195 (online) http://jssidoi.org/IRD/

2021 Volume 3 Number 2 (June)

http://doi.org/10.9770/IRD.2021.3.2(8)

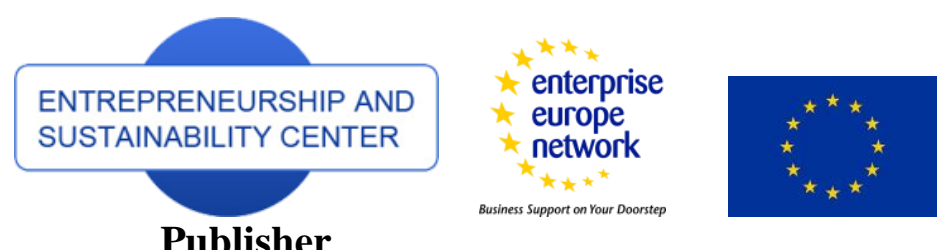

http://jssidoi.org/esc/home

\title{
CONDITIONS INFLUENCING THE CHANGE OF DEFENSE BUDGETS - THE CASE OF LITHUANIA
}

\author{
Gediminas Dubauskas \\ General Jonas Žemaitis Military Academy of Lithuania, Šilo st. 5a, Vilnius, LT-10322, Lithuania \\ E-mail: gediminas.dubauskas@lka.lt
}

Received 15 February 2021; accepted 18 April 2021; published 30 June 2021

\begin{abstract}
During the so-called Cold War the financing of the defense budget was widely discussed. The issue of financing the defense budget was widely discussed during the arms race. Since the end of the Cold War, armed conflicts have become more complex, and their causes are even more diverse than during the Cold War. They were caused by the deterioration of inter-ethnic divisions, hybrid and cyber wars over energy resources and the activities of terrorist groups. Due to the changing security dimension, a new study was conducted examining the determinants of defense spending in a changing security environment: the creation of new islands in the South China Sea to expand China's military-political power in the region; the possibility of using North Korea's nuclear energy. weapons, Russia's military maneuver in the conflict in Ukraine, its naval operation in the Black Sea, the occupation of Crimea, military operations in Syria, a change in U.S. military doctrine. The state that has spent the most military spending is returning to the creation of large military units, and to do so, the country needs to increase defense spending. Looking at how these world events work, we see one component that connects them. Strong force, expressed in military action, is used to achieve their political goals. Military power is gaining more and more influence in the formation of foreign policy, therefore the defense budget, as an instrument of foreign policy expressed in military power, is becoming an increasingly relevant object of research. Lithuania's defense budget is not as important to world politics as the United States, China or other major countries in the world, but it is relevant and significant in its region. Expenditures on the Lithuanian military budget began to increase significantly by two thousand and fourteen. It can be argued that the factor that has now influenced cost growth is Russia's military aggression in Ukraine. Nevertheless, in 2008 Russia's aggression in Georgia did not affect the growth of Lithuania's defense budget. 2008 The economic crisis may have influenced Lithuania's decision not to increase military spending. Some pressure on the country's defense budget is also related to the 2020 Pandemic crisis. The question arises as to why seemingly similar conflicts affect Lithuanian political decisions differently.
\end{abstract}

Keywords: North Atlantic Treaty Organization; Defence Spending; Sustainability; Security; Financial Management

Reference to this paper should be made as follows: Dubauskas, G., 2021. Conditions influencing the change of defense budgets - the case of Lithuania. Insights into Regional Development, 3(2), 282-288. http://doi.org/10.9770/IRD.2021.3.2(8)

JEL Classifications: H60, H56, G10, E65 
INSIGHTS INTO REGIONAL DEVELOPMENT

ISSN 2669-0195 (online) http://jssidoi.org/jesi/

2021 Volume 3 Number 2 (June)

http://doi.org/10.9770/IRD.2021.3.2(8)

\section{Introduction}

This publication shortly overviews how economic, external threats, North Atlantic Treaty Organization membership, and political factors determine changes in defense spending. The impact of these factors on Lithuania's defense spending in peacetime is analyzed. For the study of the external and internal factors of the Lithuanian defense budget and the comparison of their significance, the period of the beginning of the twenty-first century until nowadays is chosen to be analyzed. During this period, five cycles of Seimas elections took place, so based on the periods of different ideological views of the parties in power, it was analyzed how internal factors influenced the change in military budget expenditures.

There are many attempts in research to assess and identify factors influencing the military budget (Blum, 2019). Among Lithuanian authors, defense spending is examined by Jokubauskas (2015), reviewing the financing of the Lithuanian Armed Forces from the restoration of independence until the mid-twenties of the twenty first century. Sandler and George (2016), Hyde-Price (2006), and other authors examine how external threats expressed through military aggression affect states to increase power through increased funding for military spending. One of the factors chosen in the analysis of the case of Lithuania is an external threat. The paper examines its influence on the change of state defense expenditure.

In the North Atlantic Treaty Organization context, Olson and Zeckhauser (1966) began to study the phenomenon of "free riding" from the 1960s. Similar issues were analyzed by Becker and Malesky (2017), George and Sandler (2018) and many other authors. Taking into account the general theory of the financial and security burden sharing of the military alliance, this work will examine how North Atlantic Treaty Organization membership has affected the change in Lithuania's defense budget.

There are many theories examining the causality of defense budget expenditures, but taking into account the Lithuanian economy's elements and the historical context of the overviewed period, theories emphasizing internal and external factors determining the change in the defense budget were discussed. As mentioned earlier on those topics there is an internal impact of economic change and the political parties' position. In addition, there are also external threats and the impact of the North Atlantic Treaty Organization membership. A task of the paper could be to reveal the significance of factors determining the change of Lithuania's defense budget. Recent data on the growth of the country's debt in the event of a pandemic also reveal possible economic and public finance pressures on cuts in the state defense budget.

In order to implement the tasks and achieve the goal, the scientific literature of various Lithuanian and foreign authors, statistical databases, articles published on the Internet and in the press, and other relevant sources were used. Research methods used: analysis of scientific literature, analysis of statistical data, comparative research.

\section{The Influence of North Atlantic Treaty Organization Membership on the Change of Lithuanian Defense Expenditures}

Historically, the methods of collecting defense spending have varied, but the principle has remained the same to this day. As the state engages in military conflict, defense spending increases as the military campaign needs to be sustained and decreases accordingly until the state reaches its normal state, the time of peace. Citizens always pay taxes. Taxes are a means of maintaining the state and a legal obligation. Then the state, as the successor to the satisfaction of human needs, performs the necessary collective functions necessary for the existence of society. This functional relationship can be illustrated as follows: citizen - tax - government - citizen. The state budget must meet the needs necessary for the state to exist. One of the main services of this public state is to ensure the security of the citizens of the state and the integrity of the territory by protecting it from external aggression. Collectively, such national appropriations are called defense expenditures. The possible principle of operation of 
INSIGHTS INTO REGIONAL DEVELOPMENT

ISSN 2669-0195 (online) http://jssidoi.org/jesi/

2021 Volume 3 Number 2 (June)

http://doi.org/10.9770/IRD.2021.3.2(8)

defense expenditures is set out in the theory of public finances. The selfish pursuit of one's own desires creates connections between people. Thus, it is possible that a person and their group create a state to satisfy their needs, the state takes care of human security, receiving a share of the citizen's income for it. When a citizen's share of income belongs to the state and is regulated by law, it becomes a tax. The portion of taxes allocated to ensure the security of the people of the state and the integrity of the theory is called defense spending.

Hence, this section provides an overview of how Lithuania's membership in the North Atlantic Treaty Organization military alliance influenced the increase in defense spending. Taking into account the "free riding" theory, it will be examined whether in the period 2004-2018 Lithuania used the set of security measures developed by other military alliance countries, expressed in defense expenditures, and North Atlantic Treaty Organization membership allocated less to defense expenditures than North Atlantic Treaty Organization partners.

Analyzing the defense expenditures of North Atlantic Treaty Organization countries in 2004-2018, expressed as a percentage of Gross domestic product (Table 1), we see that Lithuania's defense expenditures were lower than the average in comparison with other North Atlantic Treaty Organization countries in the study period. However, taking into account North Atlantic Treaty Organization countries' aspirations to allocate two percent to defense expenditures from Gross domestic product, the North Atlantic Treaty Organization average actually is below this indicator. Nevertheless, Estonia, Greece, Latvia, Poland, UK, Lithuania and the USA have reached two percent defense expenditures from the Gross domestic product in 2018, i.e. the defense expenditure target. There also could be seen the difference between the defense spending of the US, which spends the most on defense spending, and that of Luxembourg, which spends the least, as a percentage of Gross domestic product.

Table 1. Dynamics of North Atlantic Treaty Organization defense spending as a percentage of Gross domestic product

\begin{tabular}{|c|c|c|c|c|c|}
\hline 2005 & 1.20 & 1.73 & 2.0 & 4.0 & 0.8 \\
\hline 2006 & 1.20 & 1.73 & 2.0 & 4.1 & 0.6 \\
\hline 2007 & 1.20 & 1.67 & 2.0 & 4.2 & 0.6 \\
\hline 2010 & 0.88 & 1.60 & 2.0 & 4.81 & 0.47 \\
\hline 2011 & 0.79 & 1.52 & 2.0 & 4.77 & 0.39 \\
\hline 2012 & 0.76 & 1.47 & 2.0 & 4.41 & 0.38 \\
\hline 2013 & 0.76 & 1.42 & 2.0 & 4.07 & 0.38 \\
\hline 2014 & 0.88 & 1.39 & 2.0 & 3.76 & 0.38 \\
\hline
\end{tabular}




\section{INSIGHTS INTO REGIONAL DEVELOPMENT}

ISSN 2669-0195 (online) http://jssidoi.org/jesi/

2021 Volume 3 Number 2 (June)

http://doi.org/10.9770/IRD.2021.3.2(8)

\begin{tabular}{|l|l|l|l|l|l|}
\hline 2105 & 1.14 & 1.42 & 2.0 & 3.55 & 0.44 \\
\hline 2016 & 1.48 & 1.46 & 2.0 & 3.55 & 0.40 \\
\hline 2017 & 1.72 & 1.50 & 2.0 & 3.34 & 0.52 \\
\hline 2018 & 2.00 & 1.58 & 2.0 & 3.39 & 0.54 \\
\hline
\end{tabular}

Source: North Atlantic Treaty Organization database (North Atlantic Treaty Organization, 2019) and author's calculations

The North Atlantic Treaty Organization Alliance has a common goal of ensuring the security of its members, but North Atlantic Treaty Organization members have different positions on their national security and the means by which they seek to do so. Despite declaratory agreements to increase defense spending to two percent of Gross domestic product, at least twenty percent of defense spending to new weapons and innovation, countries differ due to differing perceptions of security, differences in national public spending priorities depending on the domestic microclimate and prevailing social and economic conditions. and other significant developments influencing the holistic dimension of the country make different levels of defense spending. The "free ride" is the behavior of North Atlantic Treaty Organization members as they begin to take advantage of the security environment created by other Alliance defense capabilities. Meanwhile, for some reason, state defense spending is below the average for North Atlantic Treaty Organization defense spending. The increase in defense spending and the factor of North Atlantic Treaty Organization affiliation will be addressed through the principle of connecting factors. Whether Lithuania's membership in the North Atlantic Treaty Organization is a factor, increasing defense spending was examined using the regression method when assessing the "free riding" effect (Pauliukaitis, 2019).

In order to answer the question whether Lithuania is a "free rider", it is necessary to examine the funds allocated by Lithuania and other North Atlantic Treaty Organization countries for defense (Dubauskas, 2013). Using the method used by Murdoch and Sandler, the annual averages of defense expenditures allocated by North Atlantic Treaty Organization countries will be estimated and compared with Lithuania's defense expenditures. If Lithuania's defense expenditures are lower than the average of other North Atlantic Treaty Organization members, it will mean that Lithuania used the security dimension created by other members of the Alliance in that year, and vice versa, when Lithuania's defense expenditures are higher than the average of other North Atlantic Treaty Organization members (Murdoch, Sandler, 1984). For the comparison of defense expenditures of North Atlantic Treaty Organization countries and Lithuania, taking into account the specifics of the examined defense expenditure indicators, an indicator expressed as a percentage of defense expenditures of Gross domestic product is chosen, which enables the analysis of defense expenditures of economically different developed countries.

If a country has benefited from the North Atlantic Treaty Organization Alliance during the year and has been affected by the "free ride" effect, a coefficient of one is applied, if it has not used "free ride", a coefficient of zero is assigned, i.e., an event where costs were below the North Atlantic Treaty Organization average. The North Atlantic Treaty Organization Alliance Influence Expenditure Factor will reveal the significance of the 2004-2018 factor over the observed fifteen year period, ranging from plus one to zero, and will allow the North Atlantic Treaty Organization Alliance factor to be compared with external threat, political and economic factors.

Taking into account the defense expenditures of North Atlantic Treaty Organization countries in 2004-2018, expressed as a percentage of Gross domestic product, it is possible to calculate the total coefficient of the North Atlantic Treaty Organization Alliance's influence on defense expenditures. Such a simple statistical analysis reveals that for most of the period under review, Lithuania has benefited from the defense expenditures of North Atlantic Treaty Organization members. By examining regression analysis of Lithuanian defense expenditures from Gross domestic product and averages of North Atlantic Treaty Organization defense expenditures expressed as a percentage of Gross domestic product in 2004-2018. over the period, the relationship confirms that there is a 
INSIGHTS INTO REGIONAL DEVELOPMENT

ISSN 2669-0195 (online) http://jssidoi.org/jesi/

2021 Volume 3 Number 2 (June)

http://doi.org/10.9770/IRD.2021.3.2(8)

strong positive correlation between these variables. The Pearson correlation coefficient $r=0.93$ was obtained, indicating that in 93 percent of the compared cases Lithuania used the benefits provided by the members of the North Atlantic Treaty Organization Alliance. The value of $\mathrm{p}$ describing the statistical significance of the correlation is less than 0.05 so the value is reliable. Taking into account these indicators of statistical analysis, it can be stated that Lithuania's membership in the North Atlantic Treaty Organization had a statistically very strong connection with the "less spending" behaviours (Pauliukaitis, 2019).

The factor of Lithuania's membership in the North Atlantic Treaty Organization, expressed through the phenomenon of "free riding", is significantly correlated with defense spending, expressed as a percentage of Gross domestic product. Lithuania has used the set of security measures created by other military alliance countries, expressed in defense expenditures, and by using North Atlantic Treaty Organization membership, it has allocated less to defense expenditures than North Atlantic Treaty Organization partners. It could be concluded that Lithuania's membership in the North Atlantic Treaty Organization in 2004-2018 significantly reduced defense spending.

\section{Influence of public debt to the defence expenditures}

The correlation of defense spending with the size of the country's debt is also visible. In Lithuania, borrowing grew during the first crisis (Table 1) and also during the pandemic, as shown in Table 2. As a result of the first crisis, defense funding has declined, so pressure to reduce defense spending during a pandemic can also be expected.

Table 2. Lithuania's Debt to Gross domestic product 2008-2020 (percent)

\begin{tabular}{|c|c|c|}
\hline $\begin{array}{c}\text { Lithuania's Debt to Gross domestic } \\
\text { product, percent }\end{array}$ & $\begin{array}{c}\text { Lithuania's Debt to Gross domestic } \\
\text { product percent change, year by year }\end{array}$ & Year \\
\hline 14.6 & 0 & 2008 \\
\hline 28 & 13.4 & 2009 \\
\hline 36.2 & 8.2 & 2010 \\
\hline 37.2 & 1 & 2011 \\
\hline 39.2 & 2 & 2012 \\
\hline 38.7 & -0.5 & 2013 \\
\hline 40.5 & 1.8 & 2014 \\
\hline 42.7 & 2.2 & 2015 \\
\hline 39.7 & -3 & 2016 \\
\hline 39.1 & -0.6 & 2017 \\
\hline 33.7 & -5.4 & 2018 \\
\hline 35.9 & 2.2 & 2019 \\
\hline 47.3 & 11.4 & 2020 \\
\hline
\end{tabular}

Source: Trading Economics (2021) and author's calculations

A comparison of lending in 2008-2009 shows a clear increase in debt, and a comparison (Table 1) shows a clear decline in defense spending for less than one per cent of Gross domestic product in after crisis years, however, with a one or two years delay. At the same time, the growth of borrowing in 2020 is likely to lead to similar trends in declining defense spending, and we will feel the possible consequences a little later, given the delay effect. Such a delay effect is also examined in the works of some authors (Bove, 2017). Moreover Caruso results show that the debt burden of European countries is positively associated with the military burden of the United States and negatively associated with the average military burden of other European countries (Caruso, 2017). Thus, the defense spending of European North Atlantic Treaty Organization countries is strongly related to the defense 


\section{INSIGHTS INTO REGIONAL DEVELOPMENT}

ISSN 2669-0195 (online) http://jssidoi.org/jesi/

2021 Volume 3 Number 2 (June)

http://doi.org/10.9770/IRD.2021.3.2(8)

spending of the United States, which in turn correlates with the volume of borrowing by the United States. Returning to Lithuania's defense expenditure, as already mentioned, there is a visible negative correlation with aggregate public debt. Therefore, it can be assumed that if the impact of the pandemic on the economy decreases in the coming years, the pressure to reduce defense spending may be felt even in 2023-2025.

\section{Conclusions}

After analyzing the theories of defense expenditure, it can be stated that the causality of defense expenditure is ambiguous with the theory of realism. The change in the defense expenditure is significantly influenced by the principle of operation of the country's defense expenditure set out in the theory of public finances. The hedonistic connection to satisfy desires creates connections between people. Man creates a state to meet his needs, the state takes care of human security by receiving a share of human income for it. When the share of human income that goes to the state is determined and regulated by law, it becomes a tax. The part of the tax that is spent on ensuring the security of the people of the state and the integrity of the territory is called defense spending.

Lithuania's membership in the North Atlantic Treaty Organization has a very strong impact on Lithuania's defense spending by reducing it. The North Atlantic Treaty Organization membership factor, expressed through the 'bunny' phenomenon, correlates significantly with defense spending as a percentage of Gross domestic product. During the research period 2004-2018, Lithuania used the set of security measures created by other military alliance countries, expressed in defense expenditures, and by using North Atlantic Treaty Organization membership, it devoted less to defense expenditures than North Atlantic Treaty Organization partners. The North Atlantic Treaty Organization membership factor reduced Lithuania's defense spending. Examining the relationship between Gross domestic product as an independent variable and dependent variables (defense expenditure in euro terms and defense expenditure as a percentage of Gross domestic product per year), Gross domestic product dynamics do not affect defense expenditure as a percentage of Gross domestic product, but have a strong relationship with defense expenditure. expenditure expressed in euro as a whole. The analysis of Lithuania's defense expenditure and 3-year average Gross domestic product change indicators confirmed that Gross domestic product growth has a positive effect on state defense expenditure, but is dependent on the response time of the political apparatus to changes, and therefore reflects the country's economic changes with a delay.

In addition, the increase in public debt in 2020 is likely to trigger the trends of the financial crisis of 2008-2009, which will require cuts in defense spending, and the countries will feel the possible consequences a little later, given the lag effect.

\section{References:}

Becker, J., \& Malesky, E. (2017). The continent or the "grand large" strategic culture and operational burden-sharing in the North Atlantic Treaty Organization. International studies quarterly, 61(1), 163-180. http://doi.org/10.1093/isq/sqw039

Blum, J., \& Potrafke, N. (2019). Does a Change of Government Influence Compliance with International Agreements? Empirical Evidence for the North Atlantic Treaty Organization Two Percent Target. Defence and Peace Economics, 1-19. https://doi.org/10.1080/10242694.2019.1575141

Bove, V., Efthyvoulou, G., \& Navas, A. (2017). Political cycles in public expenditure: Butter vs guns. Journal of Comparative Economics, 45(3), 582-604. https://doi.org/10.1016/j.jce.2016.03.004

Caruso R., \& Di Domizio, M. (2017) Military spending and budget deficits: the impact of US military spending on public debt in Europe (1988-2013), Defence and Peace Economics, 28(5), 534-549. http://doi.org/10.1080/10242694.2016.1228259 
INSIGHTS INTO REGIONAL DEVELOPMENT

ISSN 2669-0195 (online) http://jssidoi.org/jesi/

2021 Volume 3 Number 2 (June)

http://doi.org/10.9770/IRD.2021.3.2(8)

Dubauskas G. (2013). Theories of Economics and Finance, Vilnius. [Access through internet]: http://www.lka.lt/lt/mokslineveikla/leidiniai/leidiniu.../ekonomika.html

George, J., \& Sandler, T. (2018). Demand for military spending in North Atlantic Treaty Organization, 1968-2015: A spatial panel approach. European Journal of Political Economy, 53, 222-236. http://doi.org/10.1016/j.ejpoleco.2017.09.002

George, J., \& Sandler, T. (2016). Military expenditure trends for 1960-2014 and what they reveal. Global Policy, 7(2), 174-184. https://doi.org/10.1111/1758-5899.12328

Hyde-Price, A. (2006). "Normative Power" Europe: a Realist Critique. Journal of European public policy, 13(2), 217-234. https://doi.org/10.1080/13501760500451634

Jokubauskas, V. (2015). Atkurtosios Lietuvos Respublikos kariuomenès pajëgumai: finansavimas, personalas ir ginkluote (Capacities of the Restored Armed Forces of the Republic of Lithuania: financing, personnel and armaments). Lietuvos metine strategine apžvalga, 13, $139-171$.

Murdoch, J. C., \& Sandler, T. (1984). Complementarity, free riding, and the military expenditures of North Atlantic Treaty Organization allies. Journal of public economics, 25(1-2), 83-101. https://doi.org/10.1016/0047-2727(84)90045-8

North Atlantic Treaty Organization (2019), Defence Expenditure of North Atlantic Treaty Organization Countries (2011-2018) Press \& Media - Presse \& Médias B-1110 Bruxelles Belgique.

Olson, M., \& Zeckhauser, R. (1966). An economic theory of alliances. The review of economics and statistics, 266-279. https://doi.org/10.2307/1927082

Pauliukaitis R., (2019). Lietuvos gynybos biudžeto kaitą lemiantys veiksniai (Factors determining the change of the Lithuanian defense budget). Master thesis. General Jonas Žemaitis Military Academy of Lithuania.

Sandler, T., \& Shimizu, H. (2014). North Atlantic Treaty Organization burden sharing 1999-2010: an altered alliance. Foreign Policy Analysis, 10(1), 43-60. https://www.jstor.org/stable/24910786

Trading Economics (2021). International Economic Data Base. [Access through Internet]:

https://tradingeconomics.com/lithuania/government-debt-to-Grossdomesticproduct

Prof. Gediminas DUBAUSKAS Dr.Sc. is a professor at the Defence Economics and Management Research group of the General Jonas Žemaitis Military Academy of Lithuania, Lithuania. Scientific field: Finance, Defence Economics, Financial Management.

ORCID ID: orcid.org/0000-0001-7789-4792

Make your research more visible, join the Twitter account of INSIGHTS INTO REGIONAL DEVELOPMENT:

@IntoInsights

Copyright (C) 2021 by author(s) and VsI Entrepreneurship and Sustainability Center

This work is licensed under the Creative Commons Attribution International License (CC BY).

http://creativecommons.org/licenses/by/4.0/

(c) (i) Open Access 